BMJ Open

Sport \&

Exercise

Medicine

\section{Risk/caution of vitamin D insufficiency for quarantined athletes returning to play after COVID-19}

To cite: Saita Y. Risk/caution of vitamin $D$ insufficiency for quarantined athletes returning to play after COVID-19. BMJ Open Sport \& Exercise Medicine 2020;0:e000882. doi:10.1136/ bmjsem-2020-000882

Accepted 9 0ctober 2020

Check for updates

(C) Author(s) (or their employer(s)) 2020. Re-use permitted under CC BY-NC. No commercial re-use. See rights and permissions. Published by BMJ.

${ }^{1}$ Orthopaedics and Sports Medicine, Juntendo University, Tokyo, Japan

${ }^{2}$ Medical Department, Iwaki Sports Club, Iwaki, Japan

Correspondence to Yoshitomo Saita; ysaita@juntendo.ac.jp
With the ongoing COVID-19 outbreak, athletes have been restricted from outdoor training. This has affected the nutritional status of athletes in various ways, especially with regard to their vitamin D status/level, which is produced in response to sun exposure. Vitamin $\mathrm{D}$ is essential for maintaining bone mass, muscle strength and physical performance. It likewise plays multiple other roles in the body, such as helping in calcium absorption and supporting the immune system. ${ }^{1}$ Therefore, sufficient vitamin $\mathrm{D}$ is indispensable not only for keeping healthy musculoskeletal conditions, but also for improving immune response, especially amidst the COVID-19 outbreak.

Insufficient vitamin D is known as a risk factor for developing stress fractures in military personnel and athletes; low level of vita$\min \mathrm{D}$ is also associated with the incidence of muscle injuries. Winter sports athletes have a greater chance of experiencing vitamin D insufficiency as compared to those engaged in spring sports. There is a high prevalence of vitamin $\mathrm{D}$ insufficiency among these athletes even in regular situations, resulting in higher risk of stress fractures, illnesses and delayed muscle recovery. ${ }^{2}$

Serum concentration of 25-hydroxyvitamin D (25-OHD) is the best indicator of vitamin D status with a long circulating half-life time (15 days). Ruohola et al demonstrated the association between the occurrence of stress fractures and low vitamin D level in 800 young Finnish men undergoing military training. ${ }^{3}$ They found that the median 25-OHD level was lower in the stress fractured group $(25.7 \mathrm{ng} / \mathrm{mL})$ than in the non-fractured group $(30.5 \mathrm{ng} / \mathrm{mL})$, with $81.8 \%$ of the fracture patients falling below the median. Shimasaki et al revealed that insufficient serum 25OHD levels of less than $30 \mathrm{ng} / \mathrm{mL}$ were associated with significantly increased odds $(\mathrm{OR}=23.3)$ for developing fifth metatarsal stress fractures in male Japanese college footballers. ${ }^{4}$ Rebolledo et al demonstrated that inadequate vitamin $\mathrm{D}$ levels showed a 3.61 higher odds of hamstring injury in NFL players. ${ }^{5}$

When athletes return to their sports after the COVID-19 hiatus, they are also exposed to the risks of excessive training and training errors. Excessive training is common early on in the athlete's season and is remedied by increasing the players' load gradually; however, given the COVID-19 situation, the athletes no longer have enough time to prepare for their competition. Meanwhile, training errors such as changes in training method, surface and shoes can also occur under restricted training situations of quarantined athletes. In addition to these abnormal situations, insufficient vitamin D level caused by less access to sunlight could synergistically increase the risk of injuries such as stress fractures and muscle strains.

According to these backgrounds, this study was performed to know whether lockdown affected the vitamin D status/level in athletes. On 7 April 2020, the Japanese prime minister declared a state of emergency due to the coronavirus pandemic. Thus, most of the football clubs stopped team training. This analysis involves a professional Japanese football team located $200 \mathrm{~km}$ north from Tokyo, which has stopped team training since 8 April 2020. Table 1 shows a comparison of the serum vitamin D (25-OHD) levels among their players in $2018(n=23)$ and $2020 \quad(n=24)$. All of these players are men. Written informed consent was obtained from players before drawing the blood. The study was approved by the Ethical Committee of the Juntendo university (approval number: \#20-157). In 2018, without the coronavirus pandemic, their vitamin D levels were higher during the spring season (May) than during the winter season (January) (29.1 vs $33.3 \mathrm{ng} / \mathrm{mL}$ on average). Contrastingly, in 2020, the results during the spring season taken on 8 May were strikingly low (23.8 vs $21.8 \mathrm{ng} / \mathrm{mL}$ ). Based on the Japan Meteorological Agency report, the daylight 


\begin{tabular}{|c|c|c|c|}
\hline & 2018 & 2020 & $P$ value \\
\hline Number of players & 23 & 24 & \\
\hline Body weight (kg) & $73.2 \pm 6.4$ & $73.7 \pm 7.7$ & n.s. \\
\hline Height $(\mathrm{cm})$ & $175.0 \pm 6.2$ & $177.0 \pm 6.7$ & n.s. \\
\hline Body mass index & $23.9 \pm 1.7$ & $23.4 \pm 1.1$ & n.s. \\
\hline Muscle mass (kg) & $35.3 \pm 3.3$ & $35.1 \pm 3.6$ & n.s. \\
\hline Age (years) & $22.7 \pm 2.0$ & $23.2 \pm 2.0$ & n.s. \\
\hline $\begin{array}{l}25-\mathrm{OHD}(\mathrm{ng} / \mathrm{mL}) \text { at } \\
\text { winter }\end{array}$ & $29.7 \pm 4.8$ & $23.8 \pm 5.1$ & $<0.001$ \\
\hline $\begin{array}{l}25-\mathrm{OHD}(\mathrm{ng} / \mathrm{mL}) \text { at } \\
\text { spring }\end{array}$ & $36.0 \pm 5.4$ & $21.8 \pm 3.6$ & $<0.001$ \\
\hline $\begin{array}{l}\text { Difference between } \\
\text { winter and spring }\end{array}$ & $+6.3 \pm 2.9$ & $-2.0 \pm 4.4$ & $<0.001$ \\
\hline \multicolumn{4}{|c|}{ Players belonging to the team in both 2018 and $2020(n=7)$} \\
\hline $\begin{array}{l}25-\mathrm{OHD}(\mathrm{ng} / \mathrm{mL}) \text { at } \\
\text { winter }\end{array}$ & $26.8 \pm 3.8$ & $24.9 \pm 5.5$ & n.s. \\
\hline $\begin{array}{l}\text { 25-OHD } \\
\text { (ng/mL) at spring }\end{array}$ & $34.8 \pm 6.8$ & $21.2 \pm 5.3$ & $<0.001$ \\
\hline $\begin{array}{l}\text { Difference between } \\
\text { winter and spring }\end{array}$ & $+8.0 \pm 3.6$ & $-3.7 \pm 3.7$ & $<0.001$ \\
\hline
\end{tabular}

hours during this period at this region were 218.7 and 200.4 hours in 2020 and 2018, respectively. In 2018, only three players $(13 \%)$ were vitamin D insufficient (less than $30 \mathrm{ng} / \mathrm{mL}$ ) in spring. However, surprisingly, all of the players were at less than $30 \mathrm{ng} / \mathrm{mL}$ in spring 2020 , although five players $(20.9 \%$ ) were above $30 \mathrm{ng} / \mathrm{mL}$ at the beginning of the season. Seven players belonged to the team for both years; their vitamin D levels were not different in winter season between 2018 and 2020, but were significantly low in spring 2020 (table 1).

These facts clearly indicate that the stay-at-home orders and restriction of outdoor training have resulted in low vitamin D levels in athletes (figure 1). This phenomenon is not just limited to athletes, but applies to anyone who has refrained from going outside given the emergency declaration. According to these observations, everyone, especially athletes and sports-loving people, must be cautious when returning to their training after the COVID-19 quarantine period to decrease the risk of sports-related injuries. The physicians who manage sports participants should recognise this fact and inform the athletes about the importance to maintain the status/level of vitamin D to prevent injury.
Initiation of the season (Winter)

Middle season (Spring)

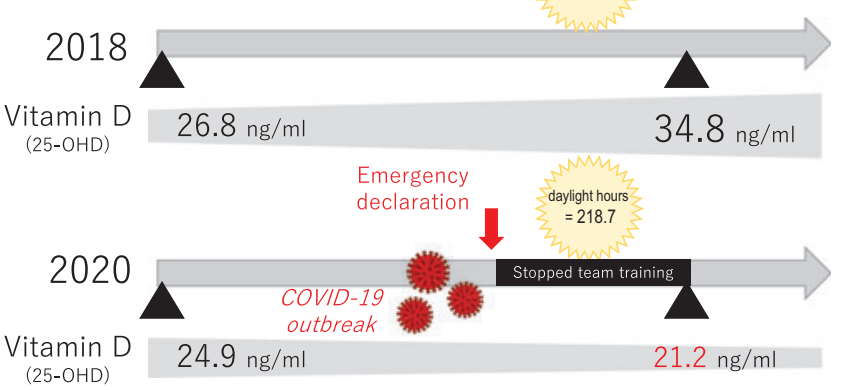

Figure 1 COVID-19 affected the serum vitamin D level.

Acknowledgements I wish to thank Satoshi Okura, Yuzo Tamura, Kazuhiko Hattori, Atsushi Hokari, all players and staffs working at lwaki sports club for supporting this work.

Contributors YS was responsible for writing manuscript, collecting data and for data analyses.

Funding The author has not declared a specific grant for this research from any funding agency in the public, commercial or not-for-profit sectors.

Competing interests None declared.

Patient consent for publication Not required

Provenance and peer review Not commissioned; externally peer reviewed.

Open access This is an open access article distributed in accordance with the Creative Commons Attribution Non Commercial (CC BY-NC 4.0) license, which permits others to distribute, remix, adapt, build upon this work non-commercially, and license their derivative works on different terms, provided the original work is properly cited, appropriate credit is given, any changes made indicated, and the use is non-commercial. See: http://creativecommons.org/licenses/by-nc/4.0/.

ORCID iD

Yoshitomo Saita http://orcid.org/0000-0003-1614-2575

\section{REFERENCES}

1 Khammissa RAG, Fourie J, Motswaledi MH, et al. The biological activities of vitamin $\mathrm{D}$ and its receptor in relation to calcium and bone homeostasis, cancer, immune and cardiovascular systems, skin biology, and oral health. Biomed Res Int 2018;9276380.

2 Owens DJ, Allison R, Close GL. Vitamin D and the athlete: current perspectives and new challenges. Sports Med 2018;48:3-16.

3 Ruohola JP, Laaksi I, Ylikomi T, et al. Association between serum 25 $(\mathrm{OH}) \mathrm{D}$ concentrations and bone stress fractures in Finnish young men. J Bone Miner Res 2006;21:1483-8.

4 Shimasaki Y, Nagao M, Miyamori T, et al. Evaluating the risk of a fifth metatarsal stress fracture by measuring the serum 25 -hydroxyvitamin $D$ levels. Foot Ankle Int 2016;37:307-11.

5 Rebolledo BJ, Bernard JA, Werner BC, et al. The association of vitamin $D$ status in lower extremity muscle strains and core muscle injuries at the National Football League combine. Arthroscopy 2018;34:1280-5. 